\title{
Documenting systemic school reform from vision to standards and assessment: the case of DLSU
}

Sterling M Plata

Correspondence:

sterling.plata@gmail.com

Department of English and Applied

Linguistics, De La Salle University,

2401 Taft Avenue1004, Manila,

Philippines

\section{Springer}

\begin{abstract}
Many schools find systemic reform difficult to implement as there are many factors and stakeholders who may hinder this initiative. This case study looks into systemic reform process in a higher education institution through policy document analysis and participant observation. It also reports the process of aligning the vision, standards, and assessment in a department. The results showed that systemic school reform can be realized with a leadership that can align the curriculum, pedagogical framework, and professional development. The consensus-building processes in the department level were also seen as a mechanism to ensure that every member of the faculty would share a common vision for the students.
\end{abstract}

Keywords: Systemic reform, Aligning standards and assessment, Transformative framework

\section{Background}

Changing workforce demands, ever-changing technology, and globalization have increased interest in educational reform. For example, several studies have confirmed that there are critical workforce skills that differ from the basic skills of the past. Murnane and Levy (1996), in their study to determine the skills needed in high wage positions in major companies in the United States, have found that the new basic skills include the hard skill or problem solving and soft skills of working in teams and communication skills. In another study, Autor et al. (2003) also confirm previous research that there is an increasing demand for problem solving, communications tasks, and coordinating activities with others. In addition, Wagner's (2012) research on the seven survival skills in the 21st century enumerate what top American companies are looking for in their employees: critical thinking and problem solving, collaboration across all networks and leading by influence, agility and adaptability, initiative and entrepreneurship, effective oral and written communication skills, accessing and analyzing information, and curiosity and imagination.

In addition, there is also a call for reform because the advent of information and communication technology (ICT) has broadened the concept of literacy from traditional literacy to multiple literacies such as academic literacy, information literacy, cultural literacy, and visual/media literacy. NCTE (2008) claims that "because technology has increased the intensity and complexity of literate environments, the twenty-first

(c) 2013 Plata; licensee Springer. This is an Open Access article distributed under the terms of the Creative Commons Attribution License (http://creativecommons.org/licenses/by/2.0), which permits unrestricted use, distribution, and reproduction in any medium, provided the original work is properly cited. 
century demands that a literate person possess a wide range of abilities and competencies, many literacies."

These new literacies and new workforce demands have motivated schools to move towards systemic reform. Systemic reform is a process of aligning the school vision, content standards, assessment, instruction, and professional development (Clune, 1998). Studies on systemic reform have used case studies to track the process of ensuring coherence in planning and implementation. For example, Clune (1998) developed a theoretical framework for case studies to identify the strengths and weaknesses of reform strategies policy and practice. He concludes that the strengths of successful systemic reforms include the strong support of policy makers, "assessment as a building block," and a mechanism for teacher development and networking.

Another related study is that of Goertz et al. (1995). They studied 12 reforming schools in order to determine the approaches and challenges they faced as they were planning and implementing changes. The challenges they observed included the difficulty of achieving a common vision, and a coherent policy for alignment and teacher development. Plata (2008) also found that teachers did not implement the national reform initiative because the implementing agency did not address the hindrances to reform. The respondents also felt that they did not get enough support for professional development. Finally, Hamann (2005) compared two cases of reform and concluded that a consistent leader was a critical component of sustainable and coherent reform. He also observed the importance of a core group of reform supporters that would inspire and lead other stakeholders. These studies on reform seem to show that systemic reform involves a clear and common vision as well as strong leaders and reform supporters to provide the necessary support for implementation. Despite several studies on reform, there seems to be a need to look into how a school and a department have achieved systemic reform. These are the two areas that this case study intends to focus on. The topic of implementation is particularly important in the Philippines because of the systemic reform that is integral to the $\mathrm{K}$ to 12 curriculum. The results of this study can start a conversation among school leaders and policy makers to discuss mechanisms to ensure a systemic educational reform from the ground up.

\section{Methods}

This study uses participant observation as well as policy document analysis to trace the process of systemic reform in De La Salle University (DLSU). The analysis of the process of systemic reform is anchored on the framework of the Education Commission of the States (1992) on systemic reform with the following components: a vision for all students, an integrated curriculum, teaching, assessment, professional development, mechanisms for collaboration, and ongoing inquiry and reflection.

The first part of the study analyzes the following documents: General Education Committee Final Report, General Education Preamble, DLSU Transformative Learning Framework, and DLSU ASIST (Academic Support for Instructional Support and Technology) Syllabus Writing Materials. These documents have been reviewed to verify how this university articulated its plan for systemic reform. 
The researcher has also participated in the following seminars in the University in order to document the implementation of the policy plans:

1. Seminar "Towards Transformative Teaching and Learning in the College of Education"

a. Module 1: Educational Philosophy and Assessment and Learning Theories, November 15, 2006

b. Module 2: Instruction and Assessment, November 22, 2006

c. Module 3: Classroom Management, December 6, 2006

1. Assessing Conceptual Change in Transformative Learning, November 19, 2008

2. Seminar on Understanding by Design, September 23, 2009

3. Training on Syllabus Writing for College Representatives, December 2011,

4. Training on Module Writing Following the Transformative Framework, March 2012

The second part of the study documents the implementation of the university reform plans in one department, the Department of English and Applied Linguistics (DEAL) by reviewing the process that it followed to revise its English 1 syllabus.

\section{Results and discussion}

De La Salle University (DLSU) is a premier Catholic university in the Philippines. DLSU is a hundred-year-old university that started a systemic reform in 2002-2003 by revising its General Education Curriculum (GE) because, according to Maridable (2006), the first GE in 1996-1997 "had to be modified in order to address the observed problems that DLSU students seemed to lack the basic competencies needed to compete in the world" and the second is to "be responsive to the changing requirements of an emerging knowledge society in globalizing environment." Maridable (2006) also points out that from February 2003 until 2006-2007, the General Education Committee (GEC) discussed the contents as well as the pedagogical framework of the Lasallian Core Curriculum (LCC). The GEC proposed the LCC with the publication of a Preamble "describing revised expectations of students and guidelines for the General Education Curriculum (GEC)" (Committee on Lasallian Pedagogical Framework, 2003). The proposed Preamble states that:

The DLSU General Education Curriculum is a set of foundational, formative, and integrative courses intended to inculcate in students a critical appreciation of the diverse fields of human knowledge, their principles and science, and their arts and methods of inquiry. The ultimate goal of the DLSU GEC is to produce in students a nationalistic and humanistic outlook and the development of a carefully reasoned adult faith in the Lasallian tradition (charism), which promotes human flourishing and inspires dedicated service to God and the Filipino nation, especially by helping the marginalized members of our society (DLSU General Education Committee, 2003, p.1).

Before the implementation of the LCC in school year 2005-2006, there was a massive training of faculty members and administrators to review and revise their curricula. 
These trainings included the discussion of the Lasallian Guiding Principles (LGP). These principles enumerate what qualities the Philippine Lasallian Family wants in a member of its community, and these are to be a "critical and creative thinker, effective communicator, reflective and lifelong learner, and service-driven citizen” (ASIST, n.d.).

\section{Transformative framework: alignment of assessment and standards}

In 2005, DLSU adopted the transformative framework to align standards, instruction, and assessment (Committee on Lasallian Pedagogical Framework, 2005). This committee presented the pedagogical framework in a document that was given during the training of faculty members. This document points out that "Teachers will need to understand the framework's focus on transformative learning and its view of the nature of knowledge, the teaching and learning process, the role of the teacher, classroom management, and assessment" (Committee on Lasallian Pedagogical Framework, 2005).

The DLSU Transformative Learning Framework (TL) explains the shift from the transmissive to the transformative learning framework, where in the former, the students are assumed to be sponges waiting to absorb what their teachers are going to give them, while in the latter, the students are assumed to possess prior knowledge that teachers have to uncover, so they can design instructions to help students discover their misconceptions and deepen their understanding of the lesson. In the transmissive mode of teaching, knowledge is a "set of given truths" as opposed to the transformative teaching's definition of knowledge as "students' conceptual growth and change" (ASIST website, n.d.). However, in the TL framework, the teacher is the facilitator guiding students in knowledge construction as they go through the process of inquiry. Consequently, assessment is authentic and performance-based rather than paper-and-pencil-based as the former measures higher order thinking skills and ELGA or Expected Lasallian Graduate Attributes.

\section{Transformative learning syllabus writing seminar: ensuring coherence of ELGA and assessment}

In order to achieve coherence of the ELGA and assessment as well as instruction, the DLSU Faculty Development Program for 2011-2012 aims to:

1. review, revise, and/or update existing GE courses syllabi;

2. review, revise, and/or update major courses syllabi;

3. train faculty in the development of modules for GE and major subjects; and

4. train faculty in module construction (Faculty Development Program, 2011)

The training for the syllabus review and revision of GE syllabi included a review of the rationale of the TL as well as a review of the backward design. This was followed by activities intended to transform faculty members' knowledge of matching ELGA and learning outcomes in their syllabus. The training also provided a template of the syllabus with 10 parts.

1. Preliminary information such as course code, college, department, class days, and instructor information

2. Course description 
3. Learning outcomes

4. Final course output

5. Rubric for assessment

6. Other requirements and assessments

7. Grading system

8. Learning plan-calendar matching learning outcomes and learning activities

9. References in APA or MLA and publication date from 2006 up

10.Class policies

The administrators such as college deans and department chairpersons were also trained in 2010 through The Lasallian Learning Leaders Congress, which aimed to:

1. Explain the connection of the Lasallian Guiding Principles with their educational philosophies, school's vision mission and GE curriculum.

2. Gain insights into how the curriculum can be designed "backward" for "deep understanding" and transferring authentic learning skills and tasks that are essential in real and adult life.

3. Develop an action plan for using key elements of Schooling by Design and Understanding by Design in the GE curriculum, programs, syllabus, and learning modules (Lasallian Learning Leaders Congress handout).

Professional development of teachers is supported by an office called DLSU Academic Support for Instructional Support and Technology (ASIST). It has four tracks: Lasallian Education, GE Curriculum, Contemporary Pedagogy, and Using Educational Multimedia Technologies (ASIST, 2012). ASIST has a website that is divided into four sections corresponding to the four tracks. Each track has downloadable references and templates. For example, the Lasallian Education section has the Lasallian Guiding Principles of Education, while the section on Curriculum has templates and sample syllabi as well as other references for writing the learning outcomes. It also has a Transformative Learning Module in beta. This allows any faculty member to plan, write, revise, and upload their modules on the ASIST website.

In addition, DLSU's Institutional Testing and Evaluation Office (ITEO) has carried out five research projects to help in systemic reform in DLSU:

(1) development of faculty evaluation forms for TL classes, (2) evaluation of the implementation of a TL program, (3) a descriptive study of TL faculty, (4) development of rubrics for TL classes, and (5) development and validation of the DLSU Thinking Skills Test (Valladolid, 2010, p. 153).

Valladolid (2010) reports that during school year 2005-2006, ITEO revised, piloted, and evaluated the TL teacher evaluation. This evaluation instrument consisted of four assessment areas: "student learning process, teacher's work, students' learning environment, and assessment of student learning." These assessment areas correspond to the aspects of Transformative Learning (Valladolid, 2010).

As can be seen in the results above, the vision for all students was the guiding force for systemic reform in curriculum and assessment. This vision resulted in the Expected 
Lasallian Graduate Attributes (ELGA). The attributes are put into each syllabus and the learning outcomes per course are matched with these outcomes. These outcomes are stated in terms of a product or demonstration that can be assessed. DLSU has implemented systemic reform by aligning the vision for students, the General Education curriculum, standards and assessment through syllabus writing and teacher development. In addition, ITEO has also aligned the teacher evaluation process with the Transformative Learning framework. Finally, mechanisms for collaboration were used for the General Education Committee as well as the Transformative Pedagogical Framework Committee. The consensus-building process continued as these committees presented their documents and solicited faculty feedback before the full implementation of systemic reform. Mechanisms for inquiry and reflection were set by the ITEO through research and development of instruments for teacher evaluation.

\section{ENGLCOM syllabus revision: aligning standards and assessment}

The second part of the study documents the process of aligning the university's pedagogical framework and the English 1 syllabus in Department of English and Applied Linguistics (DEAL). English 1 or ENGLCOM is a six-unit course divided into two components: Reading/Language (RLC) and Writing (WC). This set-up started in 20102011, and each component has a different teacher. Each class meets two times a week for one and a half hours. However, with the expansion of literacy and the move to revise the syllabus so that it is aligned with the mission and vision of the University, English 1 was revised in March 2012 following a collaborative and consultative process. The team agreed that there were three changes that the revised syllabus must have: the learning outcomes must be aligned with the ELGA or the Expected Lasallian Graduate Attribute, the tasks must be aligned with the multiliteracies framework, and the tasks for the Reading/Viewing/Language Component are to be aligned with the tasks in the Writing Component.

The study has found that DEAL followed the first two stages used by Duong et al. (2011). These two stages were drafting and panelling. Drafting and panelling followed five steps: First, the key performance areas were identified. The researcher as coordinator of ENGLCOM drafted the list after attending the Transformative Framework Syllabus Writing Workshop. Second, the draft was presented to two core members of the ENGLCOM committee members in order to review and refine the list. Third, the revised draft was emailed to 60 Department of English and Applied Linguistics (DEAL) faculty members for feedback, and after this, the researcher consolidated the feedback in order to revise the syllabus. This second version was then reviewed once more by the core committee members. The fifth stage was the focus group discussion where all teachers teaching ENGLCOM reviewed and refined the final learning outcomes. The assessment and instruction plans in the syllabus also went through the same process.

\section{ENGLCOM syllabus revision: aligning ELGA, learning outcomes, and assessment}

The multiliteracy framework was used as a basis for the researcher's review of the current syllabus. The 2011 ENGLCOM syllabus in Table 1 shows that despite the inclusion of the word "media" in the course description, the learning outcomes still focus on the traditional meaning of literacy with emphasis on reading and writing of 
Table 1 ENGLCOM syllabus (2011 version)

\section{Course Description}

English Communication (ENGLCOM) is a course that primarily focuses on the development of communicative competence in reading and writing in the context of academic, media, and other authentic texts. ENGLCOM has two components - language and reading/writing - each component meeting twice a week. The course employs various strategies in academic reading and the process approach to academic writing with corresponding activities that enhance language use. Evaluation includes non-traditional (portfolio assessment) methods.

\begin{tabular}{|c|c|}
\hline \multicolumn{2}{|l|}{ II. Desired Learning Results } \\
\hline Expected Lasallian & Desired Learning Results \\
\hline & Upon completion of the course, students are expected to: \\
\hline \multirow[t]{3}{*}{ Effective Communicator } & $\begin{array}{l}\text { 1. develop analytical and critical thinking with emphasis on inferential and } \\
\text { critical reading }\end{array}$ \\
\hline & 2. evaluate and reflect on their learning and writing competence \\
\hline & 3. apply grammar rules in their communication tasks \\
\hline \multirow[t]{3}{*}{ Critical and Creative Thinker } & $\begin{array}{l}\text { 1. develop communicative competence in reading and writing through active } \\
\text { inquiry and practice }\end{array}$ \\
\hline & 2. organize ideas for clarity, conciseness, and coherence \\
\hline & 3. identify and correct their own grammatical lapses \\
\hline \multirow[t]{3}{*}{ Reflective Lifelong Learner } & $\begin{array}{l}\text { 1. utilize reading and writing skills to accomplish their learning goals and } \\
\text { objectives }\end{array}$ \\
\hline & $\begin{array}{l}\text { 2. practice the Lasallian values of intellectual honesty, perseverance, and } \\
\text { respect for diverse opinions and ideas }\end{array}$ \\
\hline & $\begin{array}{l}\text { 3. analyze their weaknesses in grammar, word choice, and mechanics, set goals, } \\
\text { and evaluate their progress }\end{array}$ \\
\hline \multirow[t]{3}{*}{ Service-Driven Citizens } & 1. use materials in writing an informed personal stand on current social issues \\
\hline & 2. propose a personal action plan to address a social issue \\
\hline & $\begin{array}{l}\text { 3. identify as many errors in billboards/signages or campus publications and be } \\
\text { able to prepare an action plan to correct the error/s (at least } 1 \text { case) }\end{array}$ \\
\hline
\end{tabular}

printed texts. In addition, it does not separate the learning outcomes for the Reading/ Language component and Writing Component which are taught by two different teachers. Moreover, it does not specify the learning outcomes in terms of performance tasks that can be assessed. Faculty members who participated in this study pointed out that the absence of clear outcomes created differences in the way teachers taught and assessed students.

For these reasons, the ENGLCOM committee was prompted to revise the syllabus in February 2012. Table 2 shows that viewing skills are assumed to be important in order for students to become engaged citizens, and writing a brochure is added in the Reading and Language Component learning outcome for the media literacy assessment. It can also be observed that the learning outcomes in this version closely relate to the Expected Lasallian Graduate Attribute (ELGA) of service-driven citizens. This draft was reviewed and approved by two other core members of the ENGLCOM committee.

This draft was emailed to all 60 faculty members of the Department of English and Applied Linguistics for panelling. However, only 12 faculty members returned their comments. The table below shows the summary of the feedback. The common concerns were about the brochure and the critique. Eight respondents expressed their uncertainty regarding the production of a brochure. For example, one faculty member said that 
Table 2 Expanded literacy outcomes in ENGLCOM version 1 COURSE DESCRIPTION:

This course (ENGLCOM OR ENGLISH COMMUNICATION) is a foundational course that equips freshman students with the necessary reading, writing, and viewing skills needed to become engaged citizens. This course is anchored on service learning as well as self-directed learning framework. This course is divided into two components: language /reading (LRC) and writing (WC).

\section{LEARNING OUTCOMES (LO):}

On completion of the course, the student is expected to be able to do the following:

ELGA

Effective communicator

LO 1: write a definition essay on civic responsibility or on a specific social issue (WC)

Critical and Creative Thinker

Service-driven citizens

Effective communicator

LO 2: write an argumentative essay presenting the pros and cons of a solution to a specific problem that a particular disadvantaged community faces (WC)

Critical and Creative Thinker

Service-driven citizens

Reflective life long learning

LO 3: write a portfolio cover letter to reflect on his or her achievements and realizations (WC/LRC)

Effective communicator

LO 4: write a critique of an article discussing a social issue (LRC)

Critical and Creative Thinker

Service-driven citizens

ELGA

LO 5: prepare a brochure promoting a solution to a specific problem (LRC)

Effective communicator

Critical and Creative Thinker

Service-driven citizens

I teach technical writing in another school. The brochure is one of the requirements. . .If we require a brochure in ENGLCOM, I think we would have to discuss with students the elements and principles of design, and purpose and contents of a brochure. We also need to discuss with them what is technical writing and how it differs from other types of writing.

Some suggested that writing a position paper or a critique of a movie could be better than producing a brochure. On the other hand, four faculty members asked for clarification regarding the type of article that ENGLCOM students would critique. Other issues were related to the extent of the learning outcomes. Examples are given below:

Dr. A.: "I believe in the saying that Less is MORE; thus, in my opinion, we should keep the current content of ENGLCOM..."

Ms. R.: "Could we add a statement reflective of action (service)?"

Dr. G.: "May I suggest that the specific component be indicated for the required outputs."

These feedbacks were taken into consideration in the revision of the learning outcomes. The third version in Table 3 shows that the word "multiliterate" is now incorporated as an overall goal of the course. The Core Committee agreed that academic literacy, media/visual literacy, and cultural literacy were needed to expand the traditional literacy of reading and writing in ENGLCOM and to help freshman students to become better 21 st century learners and citizens. It was agreed that academic literacy 
Table 3 Multiliteracies in the learning outcomes COURSE DESCRIPTION

This course (ENGLCOM or ENGLISH COMMUNICATION) is a foundational course that equips freshman students with the necessary academic reading, writing, and viewing skills needed to become multiliterate and autonomous learners, and engaged citizens in the $21^{\text {st }}$ century. This course is anchored on transformative as well as self-directed learning frameworks. This course is divided into two components: reading/viewing/ language (RVLC) and writing (WC).

\section{LEARNING OUTCOMES (RVLC)}

On completion of the course, the student is expected to be able to do the following:

ELGA

Effective communicator

Critical and creative thinker

Effective communicator

Critical and creative thinker

Service-driven citizen

Reflective life-long learning

Reflective life-long

learning

Outcomes

LO 1: Write a reaction paper after watching a documentary.

\section{LEARNING OUTCOMES (WC)}

On completion of the course, the student is expected to be able to do the following:

\section{ELGA}

Effective

communicator

Critical and creative

thinker

Effective

communicator

Critical and creative

thinker

Reflective life-long learning

Reflective life-long

learning

\section{Outcomes}

LO 1: Write an extended definition essay on a relevant topic related to media.

LO 4: Write a portfolio cover letter that will reflect his/her realizations about visual/ media literacy, academic reading and reading process, and language use.

\section{OTHER REQUIREMENTS AND ASSESSMENTS}

Aside from the final outputs, the student will be assessed at other times during the term by the ff:

- Reading/viewing exercises

- Language exercises

-Writing exercises

\section{GRADING SYSTEM}

The student will be graded according to the following:

- RVLC 50\% (LO1 15 pts, LO2 15 pts, LO3 5 pts, LO4 and Class standing 15 pts)

-WC 50\% (LO1 15 pts, LO2 15 pts, LO3 5 pts, LO4 and Class standing 15 pts)

meant the ability to use academic conventions in writing essays, academic reading strategies for printed and online texts, and metacognition through reflection. This was translated in the Reading and Language Component Learning Outcome 1 and 4 as well as in WC Learning Outcomes 1-4. On other hand, the Core Committee adapted the 
NAMLE (National Association for Media Literary Educators) definition "media literacy is seen to consist of a series of communication competencies, including the ability to access, analyze, evaluate, and communicate information in a variety of forms, including print and non-print messages" (Baran 2012). This was translated in RVLC Learning Outcomes 1 and 2 and in WC Learning Outcome 1. Finally, the core committee agreed that freshman students need to develop cultural literacy by understanding their own culture and issues related to it. This translated to WC Learning Outcome 2.

The focus group discussion also finalized the other requirements and the grading system. The group also finalized the calendar of activities showing the alignment of the tasks and topics for reading/viewing, language, and writing. An example is shown in Table 4. These results suggest that aligning the vision for students with learning outcomes and assessment seems like walking on a tight rope, with the ELGA and learning outcomes that the leader had in mind on one hand, and the expected learning outcomes that each faculty member had in mind on the other. The balance between the two can be a messy process that can be organized through collaboration and consensus-building activities. It can be observed that the leader was there to facilitate the discussion and to allow different points of view to come into the fore. When the multiliteracy-anchored syllabus was presented to the faculty during the annual DEAL Planning, there were no questions or objections, unlike the heated discussions that took place the previous year when the process for consensus-building was not followed.

\section{Conclusions}

This study was conducted in order to review the process used by DLSU to ensure systemic reform and to report the process followed by the Department of English and Applied Linguistics in order to align the school's vision for students, the learning outcomes, and assessment. The results suggest that systemic reform at the school level needs the strong support of policymakers. In DLSU, a core group was formed in 2002 to analyze the General Education curriculum and to revise it in order to develop Lasallian graduates who possess the skills needed in the workplace. This group wrote the Lasallian Core Curriculum (LCC) through the process of extensively reviewing books on higher education and curricula of top universities, and by building consensus as to the model, components, and sub-components of the curriculum.

Another core group was formed in 2003-2004 to complement LCC with a pedagogical framework. Consequently, the leader of this core group became the Director of the DLSU teacher training office (ASIST). The results of the study indicate that this office helped the teachers though orientation about the theories and practices needed for systemic reform. This finding is in agreement with Clune (1998) and Goertz et al. (1995). They agree that strong leadership and teacher development are key factors in educational reform. The results of this study are also aligned with Hamann's (2005) finding that a consistent leader was a critical component. In this case study, the leader of the LCC core group and the leader of the Transformative Pedagogical Framework were leaders in their field in terms of educational reform and educational technology. They also held key positions in offices directly related to school policy and teacher development.

Moreover, the results suggest that this leadership ensured that systemic reform would take place at the department level through teacher training on syllabus design and 
Table 4 ENGLCOM syllabus weekly schedule sample

\begin{tabular}{|c|c|c|c|c|}
\hline \multirow{2}{*}{$\begin{array}{l}\text { Time } \\
\text { Frame }\end{array}$} & \multirow[t]{2}{*}{ Themes } & \multicolumn{2}{|c|}{ Reading, Viewing \& Language Component (RVLC) } & \multirow[t]{2}{*}{ Writing Component (WC) } \\
\hline & & Reading \& Viewing & Language & \\
\hline \multirow[t]{17}{*}{ Weeks 1-2 } & Academic Literacy & Introduction to academic reading & Academic language: Formality & Orientation \\
\hline & & Reading academic texts & Sentence sense & Diagnostic Test \\
\hline & & Recognizing rhetorical patterns & Correcting fragments, comma splices and run-on sentences & Introduction to academic writing style \\
\hline & & Reading strategies & Use of active verbs & Audience \\
\hline & & Pre-reading & & Voice \\
\hline & & While reading & & Conventions \\
\hline & & Post-reading & & Purpose \\
\hline & & Reading skills & & Process approach to writing \\
\hline & & Skimming & & Pre-writing \\
\hline & & Scanning & & Revising \\
\hline & & Noting details & & Editing \\
\hline & & Getting the main idea & & Pre-writing techniques \\
\hline & & & & Free writing \\
\hline & & & & Questioning \\
\hline & & & & Listing \\
\hline & & & & Clustering \\
\hline & & & & Structure of the traditional essay \\
\hline
\end{tabular}


module writing. It can be seen that ASIST provided the template, checklists, and samples of syllabi in the University-wide training of trainers from each college as well as on the ASIST website. The experience of the researcher was that ASIST made sure that these trained teachers followed the template of the syllabi so that they would know the right way to compose them and even teach other faculty members. Finally, it can also be seen that collaboration and consensus-building are processes that the school level and department level need to follow. This is in support of Bautista et al. (2008) who observed that consultation with stakeholders led to wider acceptance of reform. It can be assumed that through consultation, the stakeholders have a sense of "ownership" of the reform.

This case study focused on a university and one department; further studies can extend this to school or district level or regional level for $\mathrm{K}$ to 12 . With the systemic $\mathrm{K}$ to 12 reform implementation in 2011 in the Philippines, case studies on the process are crucial in assessing how leaders such as regional directors, district superintendents, and principals are interpreting the reform. Further studies can look into how other countries undergoing systemic reform have learned from their mistakes as well as from best practices. Systemic reform is a critical and a messy process, but it is a way of ensuring that reforms do transform.

Competing interests

The author declares that she has no competing interests.

Received: 6 March 2013 Accepted: 6 March 2013

Published: 2 April 2013

\section{References}

Autor, D, Levy, F, \& Murnane, R. (2003). The skill content of recent technological change: An empirical exploration. Quarterly Journal of Economics, 118(4), 1279-1333.

Baran, S. (2012). Mass communication: media literacy and culture. New York: McGraw Hill.

Bautista, C, Bernardo, A, \& Ocampo, D. (2008). When reforms don't transform. Retrieved from http://hdn.org.ph/wpcontent/uploads/2009/05/dp02_bautista_etal.pdf.

Clune, W. (1998). Toward a theory of systemic reform: The case of nine NSF statewide systemic initiatives. Retrieved from archive. http://www.wcer.wisc.edu/archive/nise/publications/Research_Monographs/vol16.pdf.

Committee on Lasallian Pedagogical Framework. (2003). Lasallian pedagogical framework for transformative learning. Retrieved from www.dlsu.edu.ph/offices/iaa/.../Lasallian_Pedagogical_Framework.doc.

Duong, MT, Cuc, NTK, \& Griffin, P. (2011). Developing a framework to measure process-oriented writing competence: A case of Vietnamese EFL students' formal portfolio assessment. RELC, 42(2), 167-185.

Education Commission of the States. (1992). Introduction to systemic reform. Education Commission of the States.

Faculty Development Program. (2011). Unpublished Module of DLSU Academic Support fo Instructional Services and Technology.

Goertz, M, Floden, R, \& O'Day, J. (1995). Studies of systemic reform. Retrieved from http://www2.ed.gov/PDFDocs/ volume1.pdf.

Hamann, E. (2005). Systemic high school reform in two states: the serendipity of state-level action. The High School Journal, 89(1), 1-17.

Maridable, J. (2006). The general education curriculum of De La Salle University-Manila in a transformative learning environment. Cuernavaca, Mexico: Paper presented at the IALU Cuernavaca VII Conference.

Murnane, RJ, \& Levy, F. (1996). Teaching the new basic skills. Economy. New York: Free Press.

NCTE. (2008). The definition of 21st century literacies. Retrieved from http://www.ncte.org/governance/literacies.

Plata, S. (2008). Exploring assessment reform policy and implementation in Philippine public secondary education. Philippine Journal of Linguistics, 38(1), 135-156.

Valladolid, V. (2010). An evaluation of the teaching-learning process: a transformative learning set-up. Educational Measurement and Evaluation Review, 1, 150-160.

Wagner, T. (2012). 7 survival skills. Retrieved from http://www.tonywagner.com/7-survival-skills.

doi:10.1186/2229-0443-3-3

Cite this article as: Plata: Documenting systemic school reform from vision to standards and assessment: the case of DLSU. Language Testing in Asia 2013 3:3. 